is important. The centromere, the nucleolus, the super-charged heterochromatin and the sticky chromosomes have a fluid surface. They run together. The normally charged chromosomes have a fibrous surface based on their fibrous framework. They stand apart. This difference between fluid and fibre would seem to depend on the polymerization of thymonucleic acid in contact with the chromosome. Here, again, there is a minor interlocking system of control, for while we saw that the nucleic acid charge controls the division of the centromere as well as of the whole thread of the sex chromosomes, the centromere itself often appears to act as the organizing centre for the charging of the chromosomes. At meiosis it then controls their pairing, which runs on a zip principle from the centromere to the two ends. In a word, the centromeres organize fibre formation both in the nucleus and on the mitotic spindle.

Thus we see a chain of reactions : the chromosome thread controls the polymerization of its thymonucleotide charge. This in turn controls the spiralization and, as would be expected, the reproduction of the thread with its genes. Hence the whole course of events can be controlled by temperature and other cell conditions as well as by the balance of heterochromatin and the organization of the nucleolus.

In this way the pattern of nuclear structure and organization is beginning to appear. But in answering some old questions we have, of course, raised far more new ones. Is the protein fibre of the chromosomes a single or a multiple chain ? Is a difference in multiplication or in charge responsible for differences in chromosome size? Why have the prosthetic groups, which represent the genes and express themselves so clearly as ehromomeres, active or inert, remained unidentified? How does the nucleic acid attach itself to these groups and so control mating and reproduction (both limited to pairs) ? Is nucleic acid the agent of reproduction, or only of separation, of the main chain or of the prosthetic groups or of both ? If it controls spiralization, is it itself polymerized in a spiral with a limited number of stable positions? How can the nucleic acid charge at prophase of meoisis be limited in quantity or arrangement so as to avoid reproduction and spiralization long enough to permit pairing ?

These and many other questions we can now attempt to deal with in a co-ordinated way. This we can do because at the same time that a new means of knowing the chemical structure and activity of the chromosomes and genes has been placed in our hands we also find ourselves provided with a variety of means of controlling this activity and modifying this structure; with the instruments, in fact, for showing cell physiology and chromosome mechanics, no longer as opposite sides, but as interlocking parts of one system.

\footnotetext{
${ }^{1}$ Mazia, D., and Jaeger, L., Proc. Nat. Acad. Sci., 25, 456 (1939).

'Kossel, A., "The Protamines and Histones" (London, Longmans 1928).

s Gulick, A., Bot. Rev., 7, 433 (1941).

‘ Caspersson, T., Naturwiss., 29, 33 (1941).

'Schmidt, W. L., Naturwiss., 24, 413 (1938).

'Astbury, W. T., Proc. 7th Int. Genet. Cong., 49-50 (1939).

'Darlington, C. D., "The Evolution of Genetic Systems"' (Cambridge, Univ. Press, 1939).

- Darlington, C. D., J. Genet., 39, 351 (1940).

- Heitz, E., Z.I.A.V., 70, 402 (1935).

20 McClintock, B., Z. Zellforsch., 21, 294 (1934).

" Darlingtru, C. D., Ann. Bot. N. S., 5, 203 (1941).
}

12 Caspersson, T., Proc. 7th Int. Genet. Cong., 85-86 (1919).

${ }^{13}$ Lesley, M. M., Genetics, 28, 485 (1938).

14 Schultz, J., et al., Proc. Nat. Acad. Sci., 28, 515 (1940).

${ }^{18}$ Caspersson, T., and Schultz, J., Proc. Nat. Acad.Sci., 26, 507 (1940).

10 Darlington, C. D., and Thomas, P. T., Proc. Roy. Soc., B, 130, 127 (1941).

${ }^{17}$ Darlington, C. D., and La Cour, L. F., J. Genet., 40, 185 (1940).

18 Darlington, C. D., and La Cour, L.F., "The Handling of Chromosomes" (London, Allen and Unwin, 1942).

10 Callan, H. G., Proc. Roy. Soc. (in the press) (1942).

20 Darlington, C. D., and Upcott, M. B., J. Genet., 41, 297 (1941).

${ }^{21}$ Koller, P. C., J. Genet., 36, 177 (1938).

${ }^{2}$ Darlington, C. D., and Dobzhansky, Th., Proc. Nat. Acad. Sci. (in the press) (1942)

as Darlington, C. D., and La Cour, L. F. (unpublished).

s4 Poddubnaja-Arnoldi, V., Planta, 25, 502 (1936).

\section{EDMOND HALLEY, 1656-1742}

BY DR. H. SPENCER JONES, F.R.S. Astronomer Royal

ON January 14, 1742, died Edmond Halley, a remarkable man whose name is familiar to the public through the famous comet that is called after him. Born on October 29, 1656, in affluent circumstances, Halley took an early interest in astronomy. He went to St. Helena for two years, 1676-78, to observe the positions of bright southern stars, and while there observed the transit of Mercury of November 7, 1677, being the first person to observe both ingress and egress at the same transit. On his return, he published in 1679 the "Catalogus Stellarum Australium" ; in this he referred to the utility of observations of transits of the inferior planets for determining the solar parallax. Reverting to this subject in the Philosophical Transactions of 1694 and 1716, he proposed that the length of time taken by the planet to cross the sun's disk should be observed at a number of suitably selected stations ; from the differences in these times, the solar parallax can be inferred. The method has the advantage of not requiring elaborate instrumental equipment but suffers from the disadvantage that it requires the visibility of both entrance and exit at the same station. The method was widely used at the transits of Venus of $1761,1769,1874$ and 1882.

Shortly after his return to England in 1678, Halley was elected a fellow of the then young Royal Society, of which in 1685 he became clerk and in 1713 one of the secretaries. In 1682 he made observations of the position of the bright comet that bears his name. It was probably this comet that turned Halley's attention to the consideration of the law of force under which an elliptic or parabolic orbit is described. $\mathrm{He}$ discovered in 1684 that for circular orbits with the sun in the centre the force for different orbits varies according to the inverse square of the distance. Being unable to solve the problem of the law of variation of the force for an elliptic orbit, he visited Newton in Cambridge in August 1684 to discuss the matter with him. He found to his surprise that Newton had already solved the problem and was able to supply the answer, but had mislaid his demonstration. Newton therefore worked out the proposition afresh and sent it in November to Halley, who made a further visit to Newton to encourage him to continue his researches. It was due to Halley's encouragement that the manuscript treatise, entitled "Philosophiæ Naturalis Principia Mathematica", which 
forms the first book of the "Principia", was presented to the Society in April 1686. The Society ordered that the book should be printed, but the state of the Society's finances at the time was such that it could not bear the expense. At the meeting of Council on June 2, 1686, it was accordingly resolved that the book be printed and "that E. Halley shall undertake the business of looking after it, and printing it at his own charge, which he engaged to do". Thus, as de Morgan remarked, Halley's "share in the produetion of the Principia entitles us to say that but for him, in all human probability, that work would not have been thought of, nor when thought of written, nor when written printed".

After Newton had demonstrated that the orbits of comets were sensibly parabolic and had devised a method for determining the elements of a comet's orbit, Halley collected all recorded observations of comets that had any claim to accuracy and computed the orbits of twenty-four comets. Among these were three that showed remarkable similarity: the comet of 1531, observed by Appian; that of 1607 , observed by Kepler ; and the comet of 1682 , observed by Halley himself. Historical records of the appear. ances of comets in 1305,1380 and 1456 confirmed his suspicions that these were all returns of the same comet. No method was then available for computing the perturbations due to the planets but, making an approximate estimate of the perturbing action of Jupiter, Halley concluded that the comet would be seen again about the end of 1758 or the beginning of 1759. "Wherefore", he remarked, "if it should return according to our prediction about the year 1758 , candid posterity will not refuse to acknowledge that this was first discovered by an Englishman." Intense interest was taken in this prediction as the time for the return of the comet approached; it was a test question put by science to Nature. The discovery of the comet on Christmas Day, 1758, and its perihelion passage on March 12, 1759 , was one of the most outstanding triumphs that Newton's theory had achieved.

In 1625 Kepler had found that the observed places of Jupiter and Saturn could not be reconciled with their accepted mean motions. The inequality in the motions of these planets was explained by Halley as the effect of their mutual attractions. A more puzzling phenomenon was discovered by Halley in 1695. By examining the records of ancient eclipses, he was led to the conclusion that there was an acceleration of the mean motion of the moon. This was amply confirmed after Halley's death, and many of the greatest mathematicians and astronomers endeavoured to find the explanation. In 1787 Laplace announced that the acceleration was the result of a gradual decrease in the eccentricity of the earth's orbit, produced by the action of the planets on the earth. In 1853, however, J. C. Adams found that the calculations of Laplace were incomplete and that the correct theoretical value of the secular acceleration of the moon's motion was only about half the observed value. The cause of the residual acceleration was not found until 1920, when the work of G. I. Taylor and H. Jeffreys proved that it was the result of a gradual slowing down of the rotation of the earth, produced by tidal dissipation of energy in shallow seas.

Another important discovery made by Halley was that of the proper-motions of the stars. In the Philosophical Transactions of 1718 he announced that Sirius, Aldebaran, Betelgeuse and Arcturus had changed their positions in the sky since the time of Ptolemy; the old idea that the stars were absolutely immovable with respect to each other was thereby disproved.

But Halley was not merely a great astronomer. $\mathrm{He}$ made important contributions to many other branches of natural philosophy. In 1688 he produced the first meteorological chart, showing the trade-winds over the oceans, based partly on his own observations. He was interested 'in the theory of the earth's magnetic field. King William III, being desirous that the variations of the compass should be observed in various parts of the Atlantic Ocean, for the benefit of navigation, gave Halley a commission as a post captain in the Royal Navy in command of the pink Paramour. The voyage lasted for two years, 16981700 , reaching as far south as lat. $52^{\circ} 30^{\prime} \mathrm{S}$. Numerous observations of the declination were made, from which a sea-chart for the Atlantic Ocean, showing the isogonals or lines of equal declination, was constructed. This chart was published in 1701 and was a valuable aid to navigation. The novel method that Halley devised for exhibiting the data is still used for magnetic charts. In 1702 he published a more extended chart, covering the whole world, which he based on all available observations. In 1701 he also carried out for the Admiralty an exact survey of the tides in the English Channel.

Halley's versatility is further indicated by his construction of the first mortality tables, thus beginning the science of life statistics.

In 1703 Halley was appointed Savilian professor of geometry at Oxford. His labours in his new position were in the neglected field of the remoter Greek geometry. He translated and edited an Arabic version of the lost work of Apollonius "De Sectione Rationis". In collaboration with David Gregory, he undertook an edition of Apollonius. But, in consequence of the sudden death of Gregory in 1708, when less than a quarter of the work had been accomplished, it was left to Halley to carry it through to completion. This edition, the first and, until the latter part of the last century, the only printed Greek text of Apollonius, was a tribute to Halley's industry and scholarship.

On the death of Flamsteed, the first Astronomer Royal, in 1719, Halley was selected in 1720 as his successor at the Royal Observatory, Greenwich, being then in the sixty-fourth year of his age. Flamsteed's instruments, the cost of which had been defrayed out of his own pocket, had been removed by his widow, who elaimed them as her own property and succeeded in maintaining her claim against the objections of the Admiralty. The Royal Observatory had thus practically to begin again. Halley obtained a grant for new instruments and equipped the Observatory with a transit instrument and a mural quadrant by Graham. The chief work he did as Astronomer Royal was to make observations of the moon through an entire saros period of eighteen years, with the view of improving tables that he had published in 1719 ; these were intended to enable longitudes at sea to be determined by the method of lunar distances. It does not appear, however, that the revision of the tables was ever attempted. Though Halley had a more versatile and original mind than Flamsteed, as Astronomer Royal he achieved less, for he did not so fully appreciate those habits of minute attention that are necessary for the attainment of a high degree of accuracy in routine programmes of astronomical observation. The work for 
which his name will remain famous was completed before his appointment to Greenwich.

Astronomer, geometer, mathematician, physicist, geographer, practical seaman and navigator, scholar and eritic-Halley filled all these roles with distinetion. As de Morgan said, "Wherever Halley laid his hand, to do work cut out by himself, he left the mark of the most vigorous intellect, the soundest judgment, the most indomitable courage against difficulties." The name of Edmond Halley will always hold an honoured place in the history of English science.

\section{CONFERENCE ON SCIENCE AND THE WAR EFFORT}

TT is natural to compare the Conference organized by the Association of Scientific Workers on January 10 and 11 with that convened last October by the Division for the Social and International Relations of Science of the British Association. The difference was striking. Whereas the October Conference was concerned with post-war planning, this canference discussed in a practical way the immediate scientific and technical problems of the War itself. Even more noticeable was the difference in the type of person who, in general, attended and spoke. Here were gathered together in the main rank-and-file men of science fresh from their work in laboratories, factories and research institutions all over the country. They came not only with grievances and criticism (of which there were plenty), but with proposals for better co-ordination of research and better utilization of our technical personnel. However, the Conference was not dominated by youth. An encouraging feature was the support it received from distinguished men of science, although the amount of this support would not appear to have been commensurate with the importance of the topics discussed. These topics ranged from the training of technical personnel and the university education of scientific workers to the organization of maximum productive effort. In addition, there were important contributions on the subjects of food and agriculture, and building, housing and A.R.P.

Sir Daniel. Hall, vice-president of the Association, who opened the Conference, emphasized that men of science must have regard to the actual machinery by which Government is carried on, otherwise their proposals would receive scant consideration. $\mathrm{He}$ stated for the consideration of the Conference that the real problem was for scientific workers and the Government itself to find the machinery which would ensure a proper method of using the expert. Captain L. F. Plugge, chairman of the Parliamentary and Scientific Committee, welcomed the Conference on behalf of his committee, and expressed the hope that his Committee would be informed of the matters discussed, so that they could be followed up. New methods in building worked out as a result of the war-time shortage of materials were described by Dr. R. Fitzmaurice, of the Building Research Station. Prof. J. B. S. Haldane pointed out that had many of the recommendations of the A.R.P. Co-ordinating Committee been adopted, not only would there have been an immense saving of life but also a saving of materials and money.

Sir John Orr treated nutrition from the point of view of its effect upon the efficiency of the worker, soldier and civilian. He pointed out that considerable increases in food production are necessary to provide a decent standard of health. Dr. H. M. Sinclair, of the Department of Biochemistry, Oxford, emphasized that the primary cause of malnutrition is poverty, with the secondary factors of ignorance and the decreased availability of familiar foodstuffs. Sir Daniel Hall outlined a post-war policy for agriculture. $\mathrm{He}$ characterized the policy of high prices as a policy of scarcity, and called for national ownership of our limited land area. Sir John Russell, Prof. H. D. Kay, Prof. F. G. Gregory, and Dr. A. Walton contributed to an extensive discussion. Prof. J. A. Carroll called for a co-ordination between school and university, and for an inquiry by such a body as the Association of Scientific Workers into the scope and content of courses. Mr. J. A. Lauwerys discussed elementary technical education, and suggested that a closer contact between schools and the industrial world would be valuable. Both sessions on education were marked by the practical detail of the discussions.

The two sessions on January 11 were devoted to the place of the industrial and Governmental scientific worker in the war effort. Prof. W. Wardlaw, and Mr. F. M. H. Markham, of the Central Register, spoke and answered criticisms of the working of the Register. Mr. E. D. Swann, of the executive committee of the Association of Scientific Workers, outlined the Association's case for a select committee to investigate the whole question of the utilization of scientific personnel and for the production executive to appoint a technical personnel committee. Prof. H. Levy asked for a place for scientific men in the commands of the fighting forces, while Mr. F. Morgan, an operational research scientist attached to an R.A.F. Command, outlined the vital work which he and his colleagues are doing, and made suggestions for its improvement. Mr. Halse, of the Industrial Committee of the Association, gave numerous examples of inefficiency in the actual working of industry. Mrs. P. Clarke spoke of the low rates of pay of explosives chemists, which compare unfavourably with those received by unskilled personnel. Drs. Garland, Stanford and McClean made out an impressive case for better medical services in industry, and the consequent effect on production.

Scientific workers from a variety of undertakings took part in the discussions. The unanimous opinion seemed to be that production is being handicapped by lack of scientific training, mismanagement and inefficiency in high places, and through the spirit of peace-time competition between firms. Lack of contact between the Services and scientific workers was emphasized. Mr. J. A. Henley summed up this part of the conference while Prof. J. D. Bernal dealt with the proceedings as a whole. He stated that if the whole truth could be told, the situation would seem to be even worse than that described by the speakers from their first-hand experience. $\mathrm{He}$ said that attempts by men of science to better the situation would meet with opposition from industry and from the Government. In his view, the opposition to scientific workers in the last few months is equivalent to sabotage and perhaps something rather stronger. He underlined the need for speed in view of the urgency of the situation.

Thus ended one of the most significant gatherings of British scientific workers held during the War. It ended on a note of action, as representations by the Association are to be made to the Ministries of Labour and of Supply as a direct result of it. It is to be hoped that the facts which came to light will be most seriously considered by these Ministries. 